\author{
Piotr RaŹniaK, SŁAWomir Dorocki, ANNA WiniarCZyK-RaŹniaK, \\ Monika PŁAZIAK, ANNA I. SZYMAŃSKA \\ Uniwersytet Pedagogiczny w Krakowie, Polska • Pedagogical University of Cracow, Poland
}

\title{
Lokalizacja ośrodków kontroli i zarządzania elementem stabilności gospodarczej ośrodków miejkich w Europie Środkowo-Wschodniej
}

\section{Centres of Command and Control Location as an Element of Economic Stability in Urban Centres of Central and Eastern Europe}

\begin{abstract}
Streszczenie: W niniejszym opracowa`niu wzięto pod uwagę najważniejsze firmy mające siedzibę zarządu w krajach Europy Środkowo-Wschodniej. Autorzy starają się odpowiedzieć na pytanie, jak zmieni się koncentracja funkcji kontrolno-zarządczych w mieście w momencie głębokiego kryzysu dominującej branży, w danym ośrodku stanowiącym jego bazę ekonomiczną. W tym celu utworzono indeks stabilności, który, w oparciu o wyniki ekonomiczne uzyskiwane przez poszczególne korporacje oraz zróżnicowanie branż, obrazuje stabilność gospodarczą ośrodków miejskich w przypadku globalnych wahań koniunkturalnych. Najbardziej odporne na kryzys okazały się Warszawa, Praga i Budapeszt. Wpływ na lokalizację najodporniejszych na kryzys miast mają odległość od państw UE 15, oddziaływanie polityczne Związku Radzieckiego widoczne w regionie w latach 1945-1990 oraz konflikty zbrojne w krajach byłej Jugosławii. Ponadto badane miasta, mimo niewielkiego wpływu na światową gospodarkę, charakteryzują się dosyć dużymi powiązaniami międzynarodowymi.
\end{abstract}

\begin{abstract}
This study takes into account the most important companies that have their head office in Central and Eastern Europe. The authors try to answer the question of how the city's position will change due to deep crisis of the dominant sector in the city. The stability index was created, based on economic results achieved by individual corporations and their sectoral diversity. It illustrates the economic stability of urban centers in the case of global fluctuations. The most resistant to the crisis proved to Warsaw, Prague and Budapest. Impact on the location of the most resilient cities is the distance from the EU-15 and the political influence of the Soviet Union is visible in the region in 1945-1990 and the armed conflict in the former Yugoslavia. In addition, the cities studied despite having a small impact on the global economy are characterized by a fairly large international connections.
\end{abstract}

Słowa kluczowe: Europa Środkowo-Wschodnia; funkcja kontroli i zarządzania; globalizacja; indeks stabilności; miasto globalne; miasto światowe

Keywords: Central and Eastern Europe; command and control function; global city; globalization; stability index; world city

Otrzymano: 25 stycznia 2016

Received: 25 January 2016

Zaakceptowano: 17 maja 2016

Accepted: 17 May 2016 


\section{Sugerowana cytacja / Suggested citation:}

Raźniak, P., Dorocki, S., Winiarczyk-Raźniak, A., Płaziak, M., Szymańska, A.I. (2016). Lokalizacja ośrodków kontroli i zarządzania elementem stabilności gospodarczej ośrodków miejskich w Europie ŚrodkowoWschodniej. Prace Komisji Geografii Przemysłu Polskiego Towarzystwa Geograficznego, 30(2), 38-54.

\section{WSTĘP}

W procesie globalizacji bardzo ważną rolę odgrywają wielkie korporacje oraz ich zarządy, które pełnią funkcję centrów decyzyjnych. To zarządy podejmują strategiczne decyzje dotyczące funkcjonowania korporacji (Zioło, 2006). Szczególnie istotna jest lokalizacja zakładów produkcyjnych i filii, umiejscowionych w wielu krajach, o działalności których decyduje zarząd (Stryjakiewicz, 2001; Płaziak, Szymańska, 2014; Szymańska, Płaziak, 2014). Tego typu grupy kapitałowe mogą skutecznie konkurować na arenie międzynarodowej (Stryjakiewicz, Wajda, 2003). Od przełomu XX i XXI wieku zauważono wzrost powiązań międzynarodowych miast, który wyrażał się lokowaniem nowych oddziałów firm w krajach, w których nie znajduje się główne centrum decyzyjne danego podmiotu gospodarczego (Dorocki, 2010; Beaverstock, Smith, Taylor, 1999).

Gospodarka nakazowo-rozdzielcza, funkcjonująca w Polsce od zakończenia II wojny światowej do 1989 roku, opierała się na planach gospodarczych, które zwykle trwały pięć lat. Zakładały one odgórnie przewidywany poziom popytu na określone dobra i usługi, podaż pieniądza i inflację, popyt na pracę i rozmieszczenie sił wytwórczych, lokalizację i strukturę inwestycji. Realia pokazywały, iż plany te często musiały być zmieniane lub pozostawały niezrealizowane (Śleszyński, 2007). W Europie Środkowo-Wschodniej wprowadzono gospodarkę rynkową, co przyczyniło się do intensyfikacji procesów globalizacji. Zarówno globalizacja, jak i integracja z Unią Europejską mają bardzo istotny wpływ na dynamikę miasta, strukturę, funkcje i procesy przestrzenne w nim zachodzące (Hamilton, 2005). W związku z przemianami polityczno-gospodarczymi zmienił się także udział poszczególnych branż w produkcie krajowym brutto. Zmniejszył się udział przemysłu na rzecz usług (Langbein, 2014). W tym okresie przeprowadzono masową prywatyzację państwowych firm, których udziałowcami stały się korporacje spoza Europy Środkowo-Wschodniej (Froot, 1994). Mimo znacznego napływu bezpośrednich inwestycji zagranicznych do omawianego regionu, ich udział w globalnym rynku jest niewielki (Haberly, Wójcik, 2015).

Obecnie w omawianej części Europy występuje niestabilna sytuacja polityczna związana z konfliktem zbrojnym pomiędzy Rosją a Ukrainą. Doprowadził on m.in. do nałożenia sankcji gospodarczych na Rosję przez kraje Unii Europejskiej i Stany Zjednoczone, przez co w odwecie rząd rosyjski nałożył sankcje na niektóre produkty importowane dotychczas przez Rosję. Może to mieć wpływ na przyszłe wyniki finansowe firm zlokalizowanych w Europie Środkowo-Wschodniej oraz branż z nimi związanych.

\section{CEL OPRACOWANia}

Koncepcje funkcji kontrolno-zarządczych miasta (Csomós, 2013), miasta globalnego (Sassen, 1991) i miasta światowego (Globalization and World Cities - GaWC, 2014) 
nie odnoszą się do odporności miast na kryzys największych firm kreujących ich potencjał. Można założyć, iż miasto z silnie rozwiniętą funkcją kontroli i zarządzania niekoniecznie musi dobrze poradzić sobie z kryzysem. W ośrodkach, w których rozwój oparty jest na monokulturze branżowej lub podmiotowej, kłopoty strategicznej firmy bądź dominującej branży mogą wpłynąć na upadek gospodarki całego ośrodka. Natomiast w miastach, w których rozwój oparty jest na istnieniu wielu dobrze prosperujących firm, będących reprezentantami różnych branż, upadek jednego podmiotu lub problemy strukturalne jednej branży zostają zniwelowane przez wysoką pozycję i dalszy rozwój innych branż obecnych w tym ośrodku. W takim przypadku można mówić o efekcie bociana - w czasie kryzysu ekonomicznego, gdy jeden lub kilka sektorów przestaje wspierać gospodarkę miasta, pozostaje jeszcze „druga noga”, czyli sektory, które oparły się kryzysowi i nadal utrzymają względną stabilizację miasta w tym zakresie (Raźniak, Dorocki, Winiarczyk-Raźniak, 2016). W Europie Środkowo-Wschodniej, oprócz praw gospodarki rynkowej, należy brać pod uwagę czynnik polityczny, jakim jest napięta sytuacja polityczna w stosunkach Unia Europejska - Rosja. Nie można wykluczyć nasilenia konfliktu na płaszczyźnie polityczno-handlowej, co może wpłynąć na wyniki finansowe poszczególnych firm i branż. W przypadku nałożenia kolejnych dotkliwych sankcji na konkretną branżę można spodziewać się obniżenia wzrostu gospodarczego, a to może niekorzystnie wpłynąć na kondycję gospodarczą danego miasta. W tej sytuacji odporność na kryzys gospodarczy jest istotnym aspektem pozycji miast w gospodarce zarówno regionalnej, jak i krajowej.

W niniejszym opracowaniu autorzy starają się odpowiedzieć na pytanie, jak zmieni się funkcja kontroli i zarządzania miasta w momencie głębokiego kryzysu dominującej branży w danym ośrodku miejskim. Kryzys jest tutaj rozumiany jako spadek wyników finansowych firm najsilniejszej branży, przez który korporacje do niej należące istotnie tracą na znaczeniu. Do tego celu utworzono wskaźnik, ukazujący pozycję miasta względem wyników finansowych poszczególnych siedzib zarządów według branży oraz stabilność ich pozycji w przypadku przemian strukturalnych w poszczególnych branżach światowej gospodarki. Wskaźnik ten pozwala także określić w sposób kompleksowy zarówno poziom rozwoju ośrodka, jak i stopień jego specjalizacji gospodarczej. Ponadto można założyć, że duża odporność na kryzys miasta jest związana z jego wysokim poziomem powiązań międzynarodowych, ponieważ straty korporacji generowane w jednym miejscu mogą być rekompensowane przez zyski na innych rynkach. Pomimo że specjalizacja $w$ wielu teoriach i planach rozwoju gospodarczego wskazywana jest jako głównie narzędzie rozwoju danej jednostki (Dziemianowicz, Szlachta, Peszat, 2014; Bański i in., 2013), pamiętać należy, że zbyt wąska specjalizacja staje się bardzo niekorzystna dla gospodarki miasta w przypadku zmian technologicznych lub w czasie światowego kryzysu (Dorocki, 2011; Gawlikowska-Hueckel, Szlachta, 2014). Dlatego współcześnie zwraca się uwagę na tzw. innowacyjną specjalizację, która wydaje się bardziej odporna na zmiany technologiczne oraz zawirowania gospodarcze (Miller, Healy, 2013; Grądziel, 2014). W poniższych rozważaniach przyjęto założenie, że zbyt wąska specjalizacja (dominacja jednej branży) wpływa na mniejszą odporność ośrodka na zmiany w światowej koniunkturze gospodarczej. 


\section{MIASTO W SYSTEMACH MIAST ŚWIATOWYCH}

Na funkcje kontrolne zarządów największych korporacji w światowej gospodarce zwrócono uwagę już dosyć dawno. Pojęcie funkcji kontroli i zarządzania miasta (command and control) pojawia się $\mathrm{w}$ wielu opracowaniach i koncepcjach opisujących potencjał miast i ich wzajemne powiązania. Jednym z najważniejszych jest praca P. Halla (1966), który określił podstawy teoretyczne koncepcji miasta światowego (world city). Według niego miasta światowe są ośrodkami politycznymi skupiającymi instytucje rządowe, związki zawodowe i federacje. Ponadto znajdują się w nich siedziby dużych firm, które prowadzą międzynarodową wymianę handlową poprzez porty morskie, międzynarodowe lotniska, główne szlaki drogowe i kolejowe. Są one również centrami finansowymi poprzez obecność central banków, firm ubezpieczeniowych i innych usług finansowych. Znajdują się w nich różne centra specjalistyczne, takie jak: główne szpitale, firmy prawnicze, wiodące uniwersytety i ośrodki badawcze, muzea, duże wydawnictwa czasopism, książek, biblioteki narodowe. Mieszczą się w nich sklepy z dobrami luksusowymi znanych marek i towarami specjalistycznymi. Są one również centrami rozrywkowymi, w których zlokalizowane są opery, teatry, sale koncertowe, kina i restauracje (Hall, 1966). Należy zwrócić uwagę, iż późniejsza koncepcja metropolii (Soldatos, 1987) w zasadzie pokrywa się z koncepcją miasta światowego, która powstała dwie dekady wcześniej. Również ta idea bazująca na wspomnianej pracy P. Halla podkreśla, że w metropolii muszą funkcjonować siedziby zarządów dużych korporacji.

W 1966 roku za miasta światowe P. Hall uznał Londyn, Paryż, Randstad (region miejski Amsterdam-Rotterdam), Zagłębie Ruhry, Moskwę, Nowy Jork i Tokio. Stwierdził także, że nie każde wielkie miasto powinno być zaliczane do tego grona, ponieważ o tym decydują jego funkcje, a nie sama wielkość wyrażona liczbą mieszkańców (Hall, 1966). Na bazie publikacji P. Halla (1966) w latach dziewięćdziesiątych XX wieku powstała organizacja Globalization and World Cities (GaWC), skupiająca badaczy zajmujących się problematyką związaną z międzynarodowymi powiązaniami miast. Naukowcy ci wzięli pod uwagę międzynarodowe powiązania największych firm usługowych (services) z branż: rozrachunkowej (accountancy), reklamowej (advertising), bankowej (banking services) oraz prawniczej (law). Opracowali hierarchię miast określającą ich powiązania międzynarodowe. W późniejszych pracach zmieniono nieznacznie metodologię, dodając do wcześniej analizowanych firm 75 największych firm na świecie (Beaverstock, Smith, Taylor, 1999). Pod koniec XX wieku najsilniejsze powiązania międzynarodowe miały Londyn i Nowy Jork, wyprzedzając zdecydowanie Hongkong, Tokio, Paryż i Singapur (Taylor, Catalano, Walker, 2002), dominujące w światowej gospodarce pod względem potencjału ekonomicznego (Raźniak, Nowotnik, 2015; Raźniak, Winiarczyk-Raźniak, Nowotnik, 2015). Nowsze opracowania nadal wskazują Londyn i Nowy Jork jako miasta o największych powiązaniach międzynarodowych. Należy zauważyć znaczny wzrost liczby miast mających znaczne powiązania międzynarodowe, w tym zwłaszcza miast azjatyckich, takich jak Pekin, Szanghaj i Seul (Taylor, Derudder, Hoyler, Ni, Witlox, 2014).

Od lat siedemdziesiątych XX wieku międzynarodowe korporacje zanotowały zdecydowany wzrost znaczenia, jednocześnie zmieniła się lokalizacja siedzib zarządów 
największych z nich (Csomós, Derudder, 2014). Wzrosła także mobilność kapitału, która jest jedną z najważniejszych cech globalizacji i koncepcji miasta globalnego (global city) (Sassen, 1991). Wydaje się, że siedziby zarządów największych światowych firm ukazują specyficzną siłę miasta pod kątem jego funkcji kontroli i zarządzania, jednak nie jest to oczywiście jedyny miernik pozycji ośrodka w globalnej sieci miast (Taylor, 2004). Funkcję kontroli i zarządzania w mieście tworzą największe światowe korporacje umieszczone na liście Forbes Global 2000. 0 ich sile świadczy to, iż w 2011 roku dysponowały gigantycznymi przychodami w wysokości 30 bln dol. Zwrócono uwagę na zdecydowaną dominację Tokio. W tym przypadku firmy zlokalizowane na jego terenie zanotowały większe przychody niż wszystkie korporacje w Chinach, mimo iż ten kraj cechuje się bardzo dynamicznym wzrostem gospodarczym (Taylor, Csomós, 2012). Rozwinięciem tych badań była koncepcja wskaźnika kontroli i zarządzania (command control index). Wzięto w nim pod uwagę lokalizację największych korporacji oraz ich przychody, dochody, wartość rynkową i wartość środków trwałych. Badania pokazały, że najważniejszymi funkcjami kontroli i zarządzania na świecie legitymowały się Tokio, Nowy Jork, Londyn, Pekin i Paryż (Csomós, 2013). Z kolei w Europie Środkowo-Wschodniej znajduje się jedynie kilkanaście firm, które mogą tworzyć funkcję command control miasta, natomiast pozytywnym aspektem jest wzrost ich liczby w latach 2006-2012 (Raźniak, Winiarczyk-Raźniak, 2014; Raźniak, Winiarczyk-Raźniak, 2015).

\section{ŹRÓDŁA INFORMACJI I DANYCH STATYSTYCZNYCH ORAZ METODY BADAŃ}

Analizie zmierzającej do opracowania indeksu stabilności poddano największe firmy mające siedzibę w krajach Europy Środkowo-Wschodniej. Uwzględniono przychody tych firm w latach 2008 i 2012 na podstawie listy sporządzonej przez firmę Deloitte (2014), która od 2008 roku tworzy ranking 500 największych firm, biorąc pod uwagę właśnie ich przychody. Są to firmy o zasięgu międzynarodowym. Dodatkowym kryterium do znalezienia się na liście jest posiadanie przez firmę przedstawicielstwa w co najmniej dwóch krajach, nie licząc siedziby. Powiązania międzynarodowe tych firm mogą być jednym z mierników zaawansowania procesów globalizacji miast lub krajów, w których się znajdują. Publikowana lista nie zawiera firm branży bankowej i ubezpieczeniowej. Są one umieszczone w osobnym zestawieniu 50 największych firm bankowych i odpowiednio - 50 ubezpieczeniowych. Badając potencjał miast/krajów, nie można ich wykluczyć, zwłaszcza w obliczu kryzysu gospodarczego. Dodano te firmy do listy 500 największych i w ten sposób powstała lista 600 najważniejszych firm Europy Środkowo-Wschodniej. Firma Deloitte w swoich rankingach wzięła pod uwagę 18 krajów: Albanię, Bośnię i Hercegowinę, Bułgarię, Chorwację, Czechy, Estonię, Węgry, Kosowo, Litwę, Łotwę, Macedonię, Mołdawię, Polskę, Rumunię, Serbię, Słowację, Słowenię, Ukrainę. Poza listą znalazły się Rosja i Białoruś, ze względu na trudności z uzyskaniem wiarygodnych wyników (Deloitte, 2014). Firmy przyporządkowano do dziewięciu branż definiowanych przez Deloitte. Są to branże: bankowa (banking), konsumencka i transportowa (consumer business and transportation), energii i surowców (energy and resources), ubezpieczeniowa (insurance), biochemiczna, medyczna i opieki zdrowotnej (life sciences and health care), produkcyjna (manufacturing), publiczna (public sector), 
nieruchomości (real estate), technologii mediów i komunikacji (technology media and telecommunications). Lokalizacje poszczególnych firm określono, przypisując je do obszarów metropolitalnych, w których znajduje się siedziba zarządu. Taką jednostką przestrzenną posługiwali się również autorzy, tworząc koncepcję miasta światowego (GaWC, 2014), miasta globalnego (Sassen, 1991) oraz współczynnika kontroli i zarządzania (Csomós, 2013).

Funkcje kontroli i zarządzania w światowej gospodarce kreują korporacje zlisty Forbes Global 2000 (Taylor, Csomós, 2012). Ten ranking wskazuje najważniejsze firmy światowe wraz z ich lokalizacją w przestrzeni geograficznej (w miastach oraz obszarach metropolitalnych). W związku z tym, aby ukazać pozycję miast Europy Środkowo-Wschodniej pokazano przychody i dochody firm notowanych na liście Delolitte Central Europe Top 500 zagregowanych do miast europejskich. Zabieg ten miał na celu wskazanie, jaką rzeczywistą pozycję posiadają miasta Europy Środkowo-Wschodniej w porównaniu z miastami europejskimi. Natomiast w szczegółowych badaniach, na poziomie regionalnym, do analiz wykorzystano omówione wcześniej dane pochodzące z listy Deloitte. Autorzy niniejszego opracowania przyjmują, iż funkcję kontroli i zarządzania w miastach Europy Środkowo-Wschodniej tworzą firmy z listy Delolitte Central Europe Top 500 oraz 100 największych firm bankowych i ubezpieczeniowych. Kryzys jest natomiast definiowany jako spadek wyników finansowych firm danej branży, poprzez który pewne korporacje zostają usunięte z listy 600 (Top500 + 100 banking i insurance) największych firm Europy Środkowo-Wschodniej, przez co tracą one możliwość tworzenia funkcji kontroli i zarządzania w regionie. Na potrzeby niniejszych badań utworzono indeks stabilności (IS), który ukazuje zmianę pozycji ośrodka miejskiego w wyniku upadku lub zachwiania danej branży gospodarki. Indeks stabilności opiera się zatem na potencjale ekonomicznym poszczególnych miast oraz zróżnicowaniu branżowym zlokalizowanych w ośrodku firm. Przeanalizowano ośrodki posiadające przynajmniej trzy branże z wyżej wymienionych, gdyż mniejsza ich liczba powodowałaby bardzo dużą niestabilność miasta w przypadku kryzysu dominującej branży.

W celu porównania pozycji poszczególnych miast obliczono wartości standaryzowane oparte na wartości średniej normalizowanych wartości przychodów ze sprzedaży oraz na dochodzie netto (x) dla poszczególnych branż (z) [1], a następnie je zsumowano, otrzymując w ten sposób syntetyczny wskaźnik potencjału (SWP) dla poszczególnych miast [2].

$$
\begin{gathered}
z_{S}=\sum \frac{x-\frac{\sum_{i=1}^{n} x_{i}}{N}}{\sqrt{\frac{\sum_{i=1}^{n}\left(x_{i}-\bar{x}_{i}\right)^{2}}{N}}} \\
S W P=\sum_{i=1}^{N} z_{s_{i}}
\end{gathered}
$$

gdzie: x - wartości sumy przychodów ze sprzedaży oraz dochód netto dla poszczególnych branż; s - branże; N - liczba miast w danej branży. 
W celu określenia branży najsilniej wpływającej na potencjał miasta odjęto od sumy wartości standaryzowanych SWP z 2012 roku wartości dla poszczególnych branż i sprawdzono, jak zmieniła się suma wartości standaryzowanych (z') dla danego miasta, uznając za 100\% sumę początkową (SWP) [3]. W ten sposób otrzymano informację, które miasta wg wskaźników ekonomicznych mają największą specjalizację branżową oraz jaka branża jest rozwinięta najlepiej, a jaka najsłabiej. Im wynik jest niższy (poniżej 100), tym bardziej świadczy to o dużej wadze danej branży dla gospodarki danego miasta. Natomiast im wynik jest wyższy (ponad 100), tym bardziej świadczy to o małej istotności ekonomicznej badanej branży w danym ośrodku miejskim. Miasta, które charakteryzują wysokie różnice pomiędzy wartościami minimalnymi i maksymalnymi otrzymanymi po odjęciu wartości standaryzowanych dla poszczególnych branż, mają więc wyraźną specjalizację branżową. Natomiast miasta, dla których różnica pomiędzy wartościami skrajnymi jest mała, rozwinęły się w sposób kompleksowy. Analizą objęto jedynie ośrodki, które miały trzy i więcej branż.

$$
z^{\prime}=\frac{S W P-z_{S}}{S W P} 100
$$

W oparciu o wartości standaryzowane oraz zmienności wartości otrzymanych po odjęciu wartości dla poszczególnych firm reprezentujących daną branżę (z') skonstruowano indeks stabilności (IS). W tym celu wartość wskaźnika (SWP) podzielono przez wartość odchylenia standardowego (SD) wartości otrzymanych po odjęciu wartości dla poszczególnych branż (z') [4]. Im wartość wskaźnika jest wyższa, tym bardziej świadczy to o jego wyższej wartości według wartości poszczególnych branż oraz większej stabilności (braku dużej specjalizacji) i równomiernym rozwoju wszystkich analizowanych branż. Pokazuje on także wpływ kryzysu finansowego głównej branży na wyniki finansowe miasta.

$$
I S=\frac{S W P}{S D_{Z^{\prime}}}
$$

\section{POZYCJA MIAST EuROPY ŚRODKOWO-WSCHODNIEJ W ŚWIETLE WSKAŹNIKA STABILNOŚCI}

W wyniku przeprowadzonych analiz można zauważyć, że w latach 2008-2012 nastąpił wzrost koncentracji przestrzennej firm z listy Central Europe Top $500+100$. W 2008 roku badane przedsiębiorstwa zlokalizowane były w 144 miastach, natomiast w 2012 roku - w 134. Jednocześnie w przypadku 2000 największych światowych korporacji (Forbes Global 2000) zauważono ich dekoncentrację przestrzenną. W 2006 roku zarządy firm z tej listy umiejscowione były w 386 miastach, w 2009 roku - w 416, a w 2012 roku - w 433 (Csomós, 2013). Dlatego wydaje się, że spadek ten w przypadku miast Europy Środkowo-Wschodniej może mieć związek z kryzysem gospodarczym oraz wycofaniem do krajów macierzystych lub likwidacją części siedzib zamiejscowych firm zagranicznych. 
W regionie Europy Środkowo-Wschodniej pod względem lokalizacji siedzib zarządów największych firm regionu dominuje Polska, w której znajduje się ok. 30\% analizowanych korporacji (Deloitte, 2014), jednak w latach 2008-2012 ich liczba zmniejszyła się o ok. 9\%. Odmienna sytuacja występuje w Czechach, gdzie nastąpił wzrost liczby firm o 23,5\% (z 85 w 2008 roku do 105 w 2012 roku). Zmiany te dokonały się przede wszystkim w miastach stołecznych tych dwóch krajów. W Warszawie nastąpił spadek ze 111 siedzib w 2008 roku do 101 w 2012 toku, natomiast w Pradze w tym samym okresie nastąpił wzrost z 60 do 77 siedzib. Widać wyraźnie, iż sukces Czech jest przede wszystkim zasługą Pragi, ponieważ poza stolicą przybyły jedynie trzy firmy. Na trzeciej pozycji znalazły się Węgry, w których w 2012 roku przybyła jedna firma w stosunku do 2008 roku (74). Wysoką pozycję zajmuje Ukraina, jednak niestabilna sytuacja polityczna może doprowadzić do ucieczki kapitału i obniżenia wyników finansowych firm zlokalizowanych w tym kraju. Z kolei niekorzystną tendencję zauważono w Bułgarii, gdzie liczba największych przedsiębiorstw spadła z 15 w 2008 do dziewięciu w 2012 roku. W tym przypadku wejście w 2007 roku do Unii Europejskiej nie wpłynęło pozytywnie na kondycję korporacji w tym kraju.

Do szczegółowej analizy wybrano miasta, w których znajdują się siedziby międzynarodowych korporacji reprezentujące co najmniej trzy różne branże gospodarki. W 2008 roku były to 24 miasta, a w 2012 roku - 23. Dniepropietrowsk i Donieck miały trzy branże tylko w 2012 roku, natomiast Belgrad tylko w 2008 roku.

Analizując zmianę liczby branż reprezentowanych przez siedziby międzynarodowych korporacji w miastach w latach 2008 i 2012, należy zaznaczyć, że wzrost odnotowały, poza wspomnianymi ukraińskimi miastami, Praga, Wilno i Poznań. Natomiast spadek liczby branż odnotowały: Budapeszt, Bratysława, Kijów, Kraków, Ryga, Toruń, Trójmiasto oraz Wrocław. W pozostałych miastach liczba branż pozostała niezmienna. W 2008 roku dziewięć branż odnotowano w Warszawie i Budapeszcie, natomiast w 2012 roku były to Warszawa i Praga. Miastami, które w badanym okresie przynajmniej w jednym roku odnotowały lokalizację siedzib reprezentujących powyżej sześciu branż, były: Kijów, Trójmiasto, Bukareszt, Zagrzeb, Bratysława i Lublana, jednakże w analizowanym okresie w żadnym z tych miast nie nastąpił wzrost liczby branż, a w przypadku połowy z nich nastąpił spadek o jedną branżę.

W badanym okresie zmieniła się również liczba siedzib korporacji. Największy wzrost od notowały Praga (przybyło 17 siedzib, czyli nastąpił wzrost o 28,4\% w stosunku do 2008 roku) i Bukareszt (siedem siedzib, 21,9\%) oraz Wilno (cztery siedziby, 44,5\%), podczas gdy największe spadki miały miejsce w przypadku Warszawy (spadek o 10 siedzib, czyli 9,1\%), Budapesztu (sześć siedzib, 11,1\%) i Sofii (cztery siedziby, 36,4\%). W pozostałych przypadkach różnica w liczbie siedzib nie wystąpiła lub była niewielka.

W przypadku zmian wartości standaryzowanych wartości przychodów ze sprzedaży oraz dochodu netto dla poszczególnych branż największy wzrost odnotowały Praga $(6,7$ pkt) i Trójmiasto $(3,6)$, a następnie: Torun $(3,2)$, Kijów $(3,2)$ i Wrocław $(2,1)$ (ryc. 1). Największe spadki wystąpiły natomiast w przypadku Warszawy $(-6,8)$, Budapesztu $(-5,7)$ oraz Lublany $(-2)$ i Wilna $(-2)$. Niezależnie od zaobserwowanych zmian w liczbie branż oraz wartości sprzedaży i dochodów, spośród analizowanych miast najwyższe wartości miały Warszawa, Praga i Budapeszt. Można uznać zatem, że to głównie 
Ryc. 1. Potencjał miast Europy Środkowo-Wschodniej w 2008 i 2012 roku

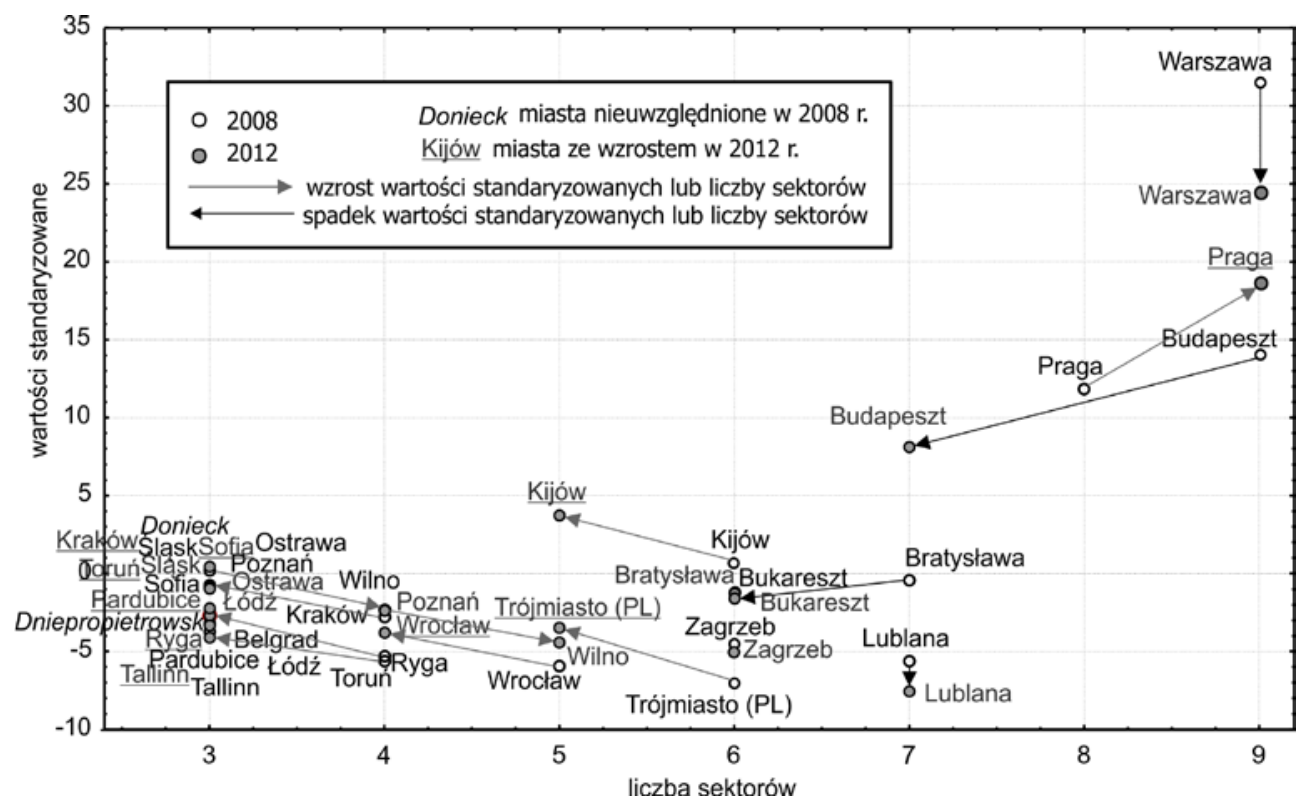

Źródło: opracowanie własne na podstawie Deloitte Top 500 Central Europe (Deloitte, 2014)

miasta stołeczne przyciągają zachodni kapitał oraz odzwierciedlają rozwój gospodarczy poszczególnych krajów. Świadczyć o tym może spadek znaczenia Budapesztu powiązany z kryzysem gospodarczym Węgier. W odniesieniu do stabilności gospodarczej w warunkach kryzysu dokonano analizy wpływu przemian strukturalnych w gospodarce.

Najmniejsze różnice w poziomie rozwoju gospodarczego, w oparciu o poziom specjalizacji branżowej miasta oraz wartości wskaźników ekonomicznych dla zlokalizowanych w mieście korporacji międzynarodowych, odnotowały: Praga i Warszawa oraz Lublana, Wilno, Zagrzeb i Trójmiasto. Spośród nich Lublana, Wilno, Zagrzeb i Trójmiasto odznaczały się niską wartością standaryzowaną wskaźników ekonomicznych dla korporacji, dlatego utrata dominującej branży powodowała względnie niskie spadki wartości dla miasta po odjęciu dominującej branży. Wysoką specjalizację i związek z jedną branżą odnotowano w przypadku Doniecka, Bukaresztu, Kijowa i Bratysławy (ryc. 2).

W przypadku wskaźnika stabilności najlepszą sytuację odnotowały Warszawa, Praga i Budapeszt, przy czym w analizowanym okresie nastąpił wzrost stabilności Pragi, przy spadku wartości dla Budapesztu i Warszawy. Obok Pragi wzrost stabilności odnotowały również miasta o najniższym wskaźniku IS, tj.: Wrocław, Ryga, Trójmiasto i Toruń (ryc. 3).

W badanych miastach branża konsumencka i transportowa najczęściej jest główną branżą (osiem miast - 34,8\%). Dominuje ona przede wszystkim w miastach położonych w krajach, które do lat osiemdziesiątych XX wieku wchodziły w skład ZSRR, a od lat dziewięćdziesiątych tworzą odrębne państwa (Litwa, Łotwa, Estonia, Ukraina). Z kolei w pięciu przypadkach dominował charakter produkcyjny $(21,7 \%)$ i były to głównie 
Ryc. 2. Największe i najmniejsze spadki standaryzowanych wartości dla miast po odjęciu dominującej branży w 2012 roku

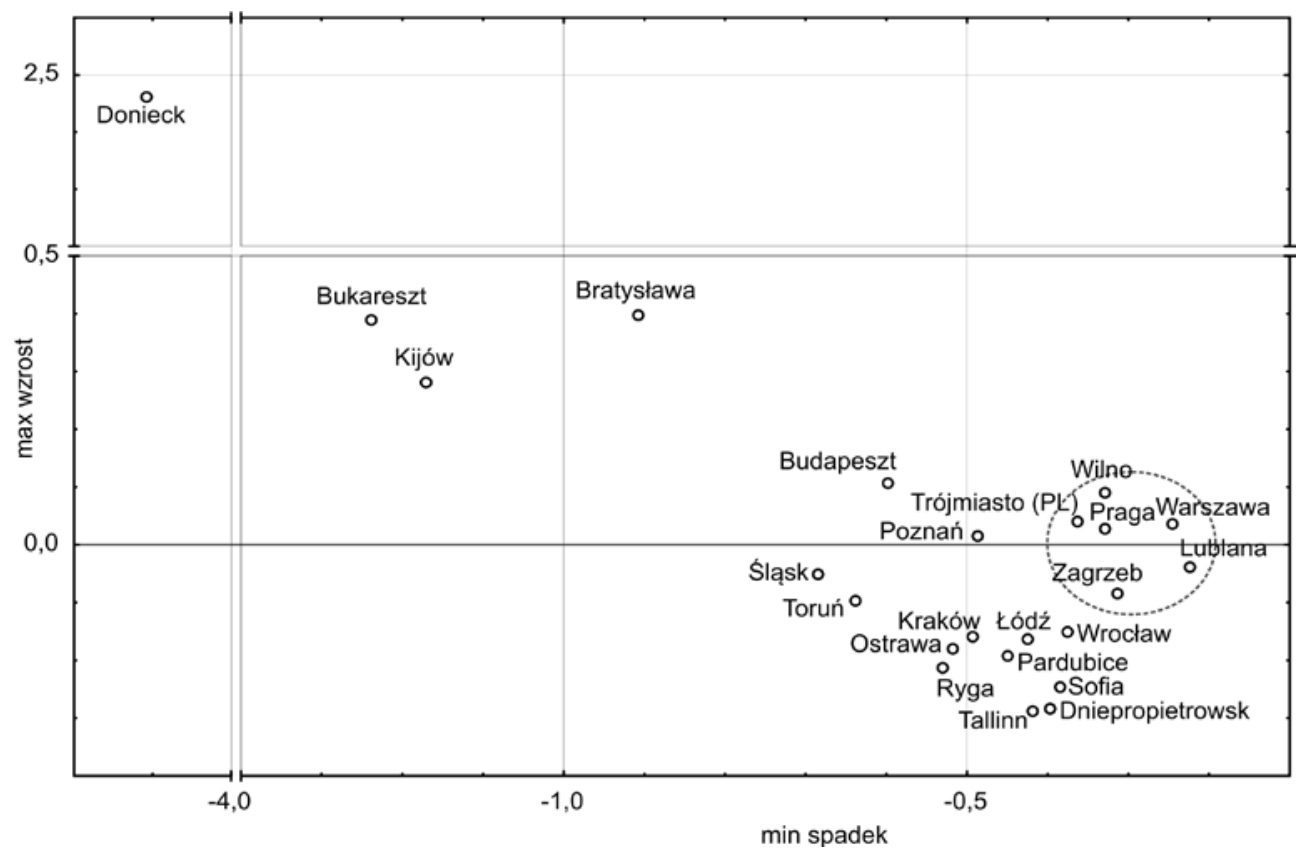

Źródło: opracowanie własne na podstawie Deloitte Top 500 Central Europe (Deloitte, 2014)

Ryc. 3. Indeks stabilności w 2008 i 2012 roku w miastach Europy Środkowo-Wschodniej

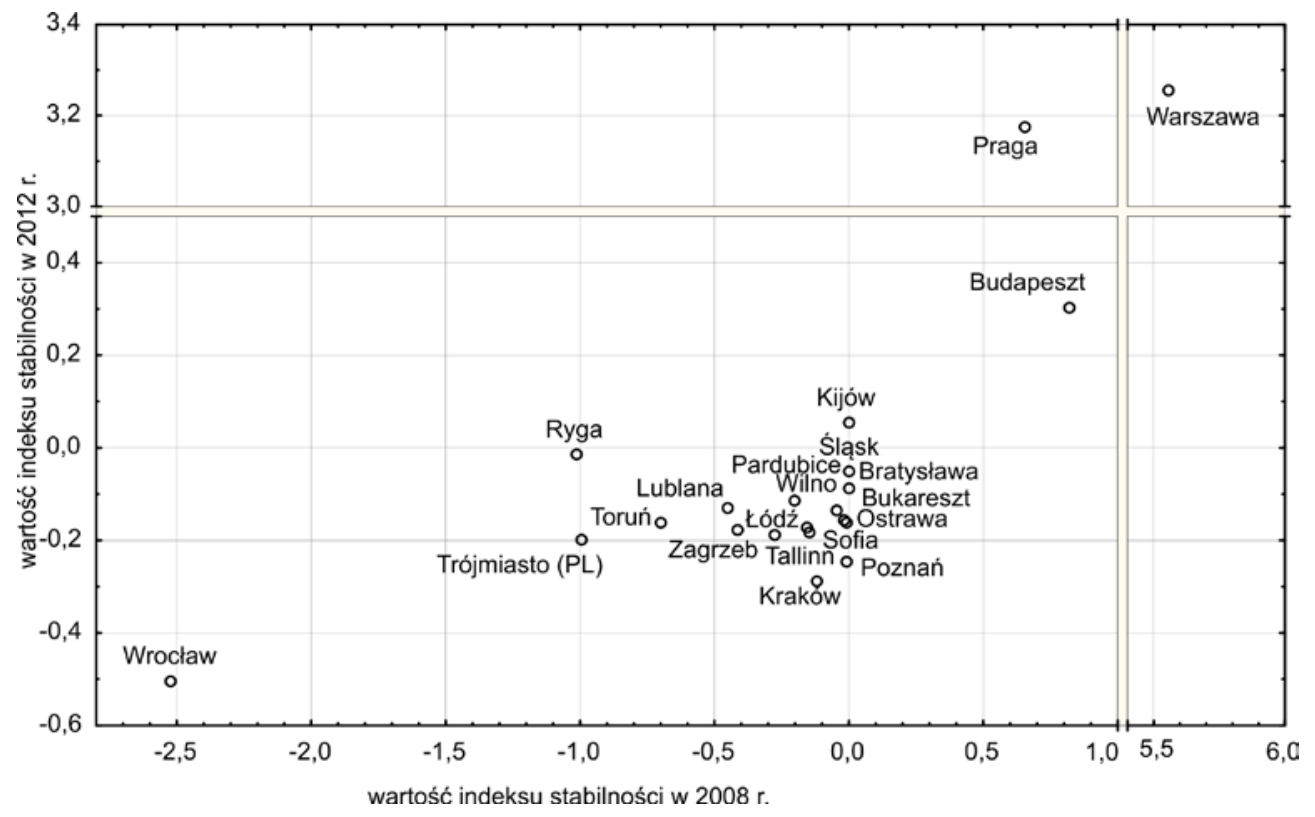

Źródło: opracowanie własne na podstawie Deloitte Top 500 Central Europe (Deloitte, 2014) 
Ryc. 4. Indeks stabilności i główna branża w miastach Europy Środkowo-Wschodniej

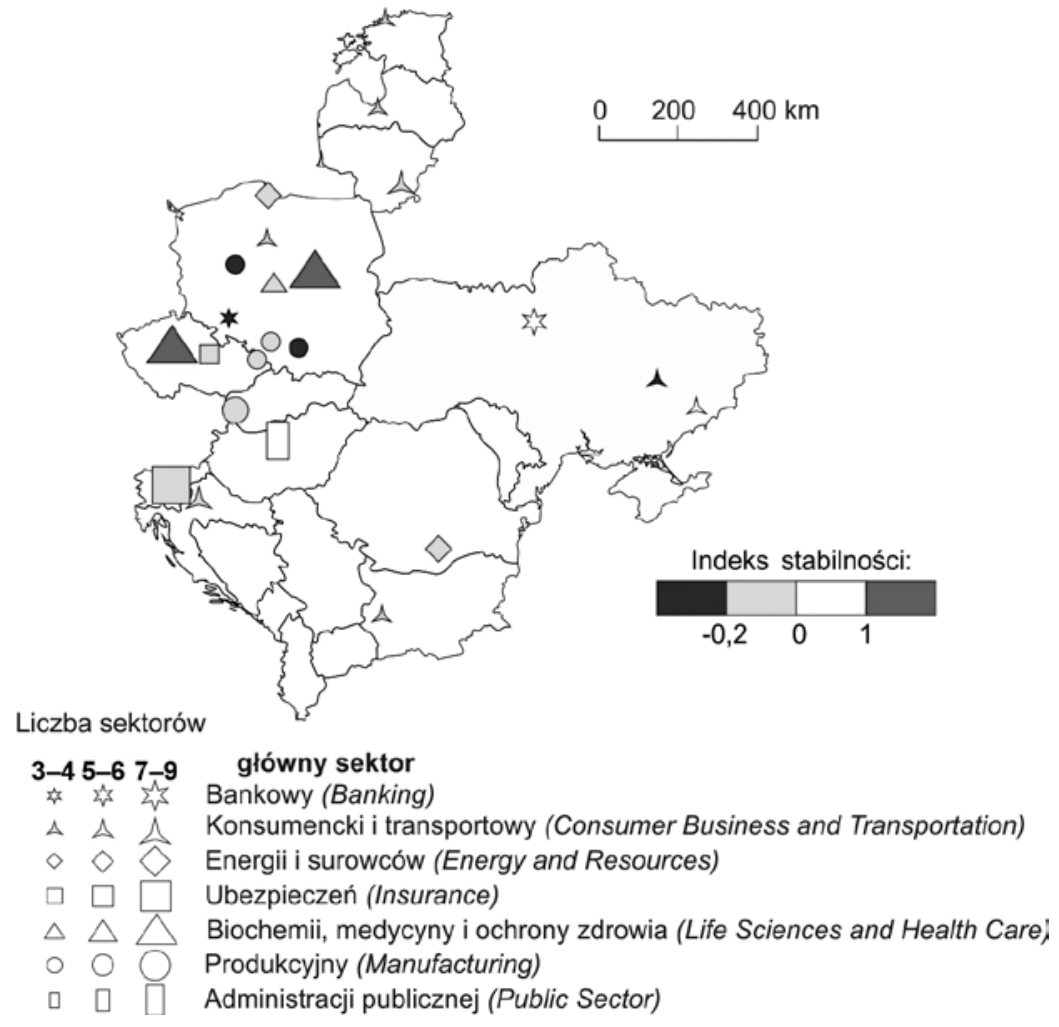

Źródło: opracowanie własne na podstawie Deloitte Top 500 Central Europe (Deloitte, 2014)

stare ośrodki przemysłowe, takie jak konurbacja katowicka i Ostrawa. Jednakże firmy tej branży zlokalizowane w Europie Środkowo-Wschodniej nie mają większego znaczenia w światowej gospodarce (Krätke, 2014). W ponad połowie badanych miast dominują więc branże konsumencka i transportowa oraz produkcyjna (łącznie 56,5\%). Na kolejnym miejscu znalazła się branża biochemiczna, medycyny i opieki zdrowotnej (trzy miasta), jednak dominowała ona w dwóch miastach o najlepiej rozwiniętej funkcji kontroli i zarządzania (Warszawa i Praga) oraz w Łodzi (ryc. 4).

Większość miast, w których znajdują się siedziby firm z listy Deloitte Top $500+$ 100 reprezentujących co najmniej trzy branże, leży w krajach sąsiadujących ze znacznie zamożniejszymi krajami UE 15. Tutaj mieszczą się ośrodki mające na swoim terenie co najmniej siedem branż (Warszawa, Praga i Lublana), natomiast w krajach położonych w większej odległości zróżnicowanie branżowe oraz liczba siedzib zarządów są zdecydowanie mniejsze. Najbardziej zdywersyfikowana pod tym względem jest Polska, na terenie której znajduje się osiem miast tego typu, a w Czechach i na Ukrainie jedynie po trzy takie ośrodki. Z drugiej strony odległość od granic UE 15 nie wpływa na stabilność miasta w czasie kryzysu. Jedynie pięć miast posiada dodatni indeks stabilności $(21,7 \%$ ogółu ośrodków) i są one położone zarówno blisko zachodnich, jak i wschodnich granic omawianego obszaru. 


\section{POZYCJA MIAST W RANKINGU INDEKSU STABILNOŚCI A MIEJSCE W RANKINGACH MIAST ŚWIATA}

Nie istnieje idealna metoda tworzenia rankingów. Każdej z nich można zarzucić niewłaściwy dobór mierników, zasugerować zmianę ich liczby lub ich składu. Poszczególne metody pokazują zjawiska pod różnym kątem. W tab. 1 ukazano miejsce miast w rankingach: miast światowych, miast globalnych i wskaźnika kontroli i zarządzania. Celem było sprawdzenie, czy miasta Europy Środkowo-Wschodniej odgrywają znaczącą rolę w świecie.

Tab. 1. Pozycja miast w rankingu indeksu stabilności a miejsce $\mathrm{w}$ rankingach miast świata

\begin{tabular}{|c|c|c|c|c|c|}
\hline \multirow[b]{2}{*}{$\begin{array}{c}\text { Ranking } \\
\text { według indeksu } \\
\text { stabilności }\end{array}$} & \multirow[b]{2}{*}{ Miasto } & \multirow[b]{2}{*}{ Kraj } & \multicolumn{3}{|c|}{ Miejsce w rankingu: } \\
\hline & & & $\begin{array}{c}\text { miast } \\
\text { światowych } \\
(\text { GAWC })\end{array}$ & $\begin{array}{c}\text { miast } \\
\text { globalnych } \\
\text { (według: } \\
\text { Sassen, 2009) }\end{array}$ & $\begin{array}{c}\text { kontroli } \\
\text { i zarządzania } \\
\text { (według: } \\
\text { Csomós, 2013) }\end{array}$ \\
\hline 1 & Warszawa & Polska & 32 & 59 & 131 \\
\hline 2 & Praga & Czechy & 44 & 49 & 193 \\
\hline 3 & Budapeszt & Węgry & 62 & 52 & 189 \\
\hline 4 & Kijów & Ukraina & 67 & $\mathrm{x}$ & $\mathrm{x}$ \\
\hline 5 & Donieck & Ukraina & $\mathrm{x}$ & $\mathrm{x}$ & $\mathrm{x}$ \\
\hline 6 & Ryga & Łotwa & 102 & $\mathrm{x}$ & $\mathrm{x}$ \\
\hline 7 & $\begin{array}{l}\text { Konurbacja } \\
\text { katowicka }\end{array}$ & Polska & $\mathrm{x}$ & $\mathrm{x}$ & $\mathrm{x}$ \\
\hline 8 & Bratysława & Słowacja & 92 & $\mathrm{x}$ & $\mathrm{x}$ \\
\hline 9 & Pardubice & Czechy & $\mathrm{x}$ & $\mathrm{x}$ & $\mathrm{x}$ \\
\hline 10 & Lublana & Słowenia & 160 & $\mathrm{x}$ & $\mathrm{x}$ \\
\hline 11 & Wilno & Litwa & 149 & $\mathrm{x}$ & $\mathrm{x}$ \\
\hline 12 & Bukareszt & Rumunia & 68 & $\mathrm{x}$ & $\mathrm{x}$ \\
\hline 13 & Ostrawa & Czechy & $\mathrm{x}$ & $\mathrm{x}$ & $\mathrm{x}$ \\
\hline 14 & Toruń & Polska & $\mathrm{x}$ & $\mathrm{x}$ & $\mathrm{x}$ \\
\hline 15 & Łódź & Polska & $\mathrm{x}$ & $\mathrm{x}$ & $\mathrm{x}$ \\
\hline 16 & Zagrzeb & Chorwacja & 124 & $\mathrm{x}$ & 375 \\
\hline 17 & Sofia & Bułgaria & 101 & $\mathrm{x}$ & $\mathrm{x}$ \\
\hline 18 & Tallinn & Estonia & 150 & $\mathrm{x}$ & $\mathrm{x}$ \\
\hline 19 & Trójmiasto & Polska & $\mathrm{x}$ & $\mathrm{x}$ & $\mathrm{x}$ \\
\hline 20 & Poznań & Polska & 212 & $\mathrm{x}$ & $\mathrm{x}$ \\
\hline 21 & Kraków & Polska & 177 & $\mathrm{x}$ & $\mathrm{x}$ \\
\hline 22 & Wrocław & Polska & 200 & $\mathrm{x}$ & $\mathrm{x}$ \\
\hline 23 & Dniepropietrowsk & Ukraina & $\mathrm{x}$ & $\mathrm{x}$ & $\mathrm{x}$ \\
\hline $\begin{array}{l}\text { Wartość korelacj } \\
\text { indeksu stabilno } \\
\text { rankingami }\end{array}$ & $\begin{array}{l}\text { i rang Spearmana } \\
\text { ści z pozostałymi }\end{array}$ & & 0,860 & $-0,5$ & 0,8 \\
\hline $\begin{array}{l}\text { Wartość p (wsp. } \\
\text { z p <,05000) }\end{array}$ & korelacji są istotne & & 0,00004 & 0,66666 & 0,20000 \\
\hline
\end{tabular}

Źródło: opracowanie własne 
Odporność na kryzys miast Europy Środkowo-Wschodniej pokrywa się zatem z ich miejscem w rankingu ukazującym powiązania międzynarodowe (tab. 1). Potwierdza to współczynnik rang Spearmana, którego najwyższą wartość $(0,86)$ mają miasta światowe (GaWC, 2014). Natomiast w przypadku zbieżności pomiędzy rankingiem miast wg indeksu stabilności a dwoma pozostałymi rankingami zależność jest nieistotna statystycznie ze względu na małą liczbę porównywalnych danych. Analizowane miasta Europy Środkowo-Wschodniej mają dosyć duże powiązania międzynarodowe. Aż 15 $(65,2 \%)$ z nich jest notowanych w klasyfikacji world cities. Stwierdzono, że miasta z największą odpornością na kryzys (Warszawa, Praga, Budapeszt i Kijów) jednocześnie legitymują się największymi powiązaniami międzynarodowymi. Większość analizowanych miast znajdujących się w rankingu world cities to równocześnie ośrodki stołeczne; wyjątkiem są trzy miasta polskie niepełniące takiej funkcji: Kraków (gamma-cities), Wrocław (high sufficieny cities) i Poznań (high sufficieny cities), które należą przy tym do najbardziej rozwiniętych pod względem społeczno-ekonomicznym miast w Polsce (Raźniak, 2009).

Miasta regionu znajdują się zdecydowanie niżej w hierarchii przy porównaniu ich potencjału ekonomicznego i społecznego do miast na świecie (global city, command control index). Jedynie Warszawa, Praga i Budapeszt mają na tyle duży potencjał, aby można je było zaliczyć do miast globalnych (Sassen, 2009). Najodporniejsza na kryzys Warszawa zajmuje najniższe miejsce spośród wymienionych miast (59), podczas gdy Praga notowana jest 10 pozycji wyżej, a Budapeszt wyprzedził stolicę Polski o siedem miejsc. Funkcje kontrolne miast koncentrują się przede wszystkim w USA, Europie Zachodniej i Azji Wschodniej (Csomós, 2013). Pod tym względem miasta analizowanego regionu praktycznie nie mają znaczenia w światowej gospodarce. Słabo zaznacza się jedynie pozycja następujących miast omawianego regionu: Zagrzebia (375 miejsce), Pragi (193), Budapesztu (189) i Warszawy (131).

\section{PodsumoWANiE}

W Europie Środkowo-Wschodniej najważniejszymi ośrodkami kontroli i zarządzania są Warszawa, Praga i Budapeszt. Mają one największą odporność na kryzys gospodarczy i duże powiązania międzynarodowe. Jednocześnie ich potencjał pozwala im na pełnienie dosyć znaczącej funkcji w światowej gospodarce. Z kolei w ponad połowie badanych miast dominowały branże konsumencka i transportowa oraz produkcyjna. W związku z tym kryzys gospodarczy tych branż mógłby najbardziej wpłynąć na zachwianie funkcji kontrolno-zarządczej miast Europy Środkowo-Wschodniej.

Generalnie można stwierdzić, iż siła oddziaływania dawnego Związku Radzieckiego może mieć negatywny wpływ na obecną funkcję kontroli i zarządzania w miastach Europy Środkowo-Wschodniej. Najwięcej omawianych miast było zlokalizowanych na terenie krajów, które tworzyły odrębne państwa po II wojnie światowej, ale jednak pozostawały one pod silnym wpływem politycznym ówczesnego ZSRR (Polska, Czechy, Słowacja, Węgry, Rumunia, Bułgaria). Dalej natomiast znajdują się byłe republiki radzieckie, odznaczające się mniejszą liczbą siedzib zarządów. Najsłabiej reprezentowane są państwa powstałe po rozpadzie Jugosławii. Przyczyną tego mogą być wojny 
domowe, które dotykały ten teren w latach dziewięćdziesiątych XX wieku. Niepokoje militarne i tworzenie nowych granic nigdy nie sprzyjają rozwojowi gospodarczemu, przez co także firmy z tego regionu nie wykształciły się na tyle, aby uzyskać znaczenie w Europie. Dominacja Lublany i Zagrzebia w byłej Jugosławii może wynikać m.in. z tego, iż na tym terenie nie było większych starć zbrojnych i dosyć szybko weszły one na ścieżkę rozwoju gospodarczego.

Jak wspomniano na wstępie, specjalizacja oraz rozwój klastrowy to jedne z podstawowych narzędzi rozwoju gospodarczego różnego szczebla jednostek terytorialnych, jednak oparcie rozwoju ośrodka na zbyt wąskiej domenie powoduje ryzyko upadku gospodarki miasta w przypadku schyłku branży lub kryzysu gospodarczego. Wydaje się, że ośrodki, które w wyniku wzrostu gospodarczego rozwinęły wiele branż, są bardziej odporne na wahania koniunktury gospodarczej niż miasta oparte na monorozwoju. Przykładem mogą być takie miasta, jak Łódź (Jakóbczyk-Gryszkiewicz, 2011) czy amerykański Pittsburgh (Duranton, Puga, 2000), w których upadek jednej branży pociągnął za sobą stagnację gospodarki całego miasta. Podobnie w przypadku lokalizacji siedzib korporacji - w miastach, w których znajdują się przedstawicielstwa reprezentujące różne branże gospodarki, trudności związane z kryzysem powinny być mniej odczuwalne niż w miastach, w których dominuje tylko jedna branża.

\section{Literatura \\ References}

Bański, J., Czapiewski, K., Ferenc, M., Mazur, M., Konopski, M., Solon, B. (2013). Badanie potencjałów i specjalizacji województwa podkarpackiego. Warszawa: Instytut Geografii i Przestrzennego Zagospodarowania Polskiej Akademii Nauk.

Beaverstock, J.V., Smith, R.G., Taylor, P.J. (1999). A roster of world cities. Cities, 16(6), 445-458.

Csomós, G., Derudder, B. (2014). Ranking Asia-Pacific cities: Economic performance of multinational corporations and the regional urban hierarchy. Bulletin of Geography. Socio-economic Series, 25, 69-80.

Csomós, G. (2013). The Command and Control Centers of the United States (2006/2012): An Analysis of Industry Sectors Influencing the Position of Cities. Geoforum, 12(50), 241-251.

Deloitte (2014, 3 października). Pozyskano z www.deloitte.com

Dorocki, S. (2010). Współczesne procesy internacjonalizacji produkcji i delokalizacji przemysłu samochodowego Francji. Prace Komisji Geografii Przemysłu Polskiego Towarzystwa Geograficznego, 16, 125-136.

Dorocki, S. (2011). Wpływ kryzysu gospodarczego na przemiany struktur regionalnych Francji. Prace Komisji Geografii Przemysłu Polskiego Towarzystwa Geograficznego, 17, 67-86.

Duranton, G., Puga, D. (2000). Diversity and Specialisation in Cities: Why, Where and When Does it Matter? Urban Studies, 37(3), 533-555.

Dziemianowicz, W., Szlachta, J., Peszat, K. (2014). Potencjały rozwoju i specjalizacje polskich województw. Warszawa: Ministerstwo Infrastruktury i Rozwoju.

Froot, K.A. (1994). Foreign Direct Investment in Eastern Europe: Some Economic Considerations. W: O. Blanchard, K. Froot, J. Sachs (red.). Transition in Eastern Europe, 2, 293-318. Chicago: University of Chicago Press.

Gawlikowska-Hueckel, K., Szlachta, J. (red.) (2014). Wrażliwość polskich regionów na wyzwania współczesnej gospodarki. Implikacje dla polityki rozwoju regionalnego. Warszawa: Wolters Kluwer.

Globalization and World Cities (GWC) (2014, 15 stycznia). Pozyskano z www.lboro.ac.uk

Grądziel, A. (2014). Strategia inteligentnej specjalizacji stymulatorem rozwoju gospodarczego regionów. Studia i Prace Wydziału Nauk Ekonomicznych i Zarzq̨dzania Uniwersytetu Szczecińskiego, 37(2), 243-253.

Haberly, D., Wójcik, D. (2015). Regional Blocks and Imperial Legacies: Mapping the Global Offshore FDI Network. Economic Geography, 91(3), 251-280. 
Hall, P. (1966). The World Cities. London: Heinemann.

Hamilton, I.F.E. (2005). The external forces: Towards globalization and European integration. W: F.E.I. Hamilton, K. Dimitrovska Andrews, N. Pichler-Milanović (red.). Transformation of cities in central and Eastern Europe: Towards globalization. Tokyo-New York-Paris: United Nations University Press, 79-115.

Jakóbczyk-Gryszkiewicz, J. (2011). Łódź u progu XX wieku. Studia Miejskie, 4, 131-138.

Krätke, S. (2014). How Manufacturing Industries Connect Cities across the World: Extending Research on 'Multiple Globalizations'. Global Networks, 14(2), 121-147.

Langbein, J. (2014). European Union Governance towards the Eastern Neigbourhood: Transcending or Redrawing Europe's East-West Divide? Journal of Common Marked Studies, 52(1), 157-174.

Miller, M., Healy, A. (2013). Preparation of Smart Specialisation Strategy for Poland, Draft Report. DG Research and Innovation.

Płaziak, M., Szymańska, A.I. (2014). Role of Modern Factors in the Process of Choosing a Location of an Enterprise. Procedia - Social and Behavioral Sciences, 120, 72-83.

Raźniak, P. (2009). Znaczenie rozwoju społeczno-gospodarczego polskich metropolii i ich oddziaływanie na otaczające je obszary. W: A. Chodyński (red.). Współczesne zagadnienia zarządzania przedsiębiorstwo-biznes-region. Kraków: Oficyna Wydawnicza AFM, 109-122.

Raźniak, P., Dorocki, S., Winiarczyk-Raźniak, A. (2016). Permanence of the economic potential of cities based on sector development. Chinese Geographical Science (w druku).

Raźniak, P., Nowotnik, D. (2015). Pozycja gospodarcza miast Europy Środkowo-Wschodniej na tle świata. Ekonomia Międzynarodowa, 9, 23-39.

Raźniak, P., Winiarczyk-Raźniak, A. (2014). Sytuacja finansowa korporacji europejskich w dobie kryzysu. Prace Komisji Geografii Przemysłu Polskiego Towarzystwa Geograficznego, 27, 99-117.

Raźniak, P., Winiarczyk-Raźniak, A. (2015). Did the 2008 global economic crisis affect large firms in Europe? Acta Geographica Slovenica, 55(1), 128-139.

Raźniak, P., Winiarczyk-Raźniak, A., Nowotnik, D. (2015). Central and Eastern European Cities in globalized world. Socio-Economic Problems and the State, 12(1), 22-33.

Sassen, S. (1991). The Global City: New York, London, Tokyo. Princeton: Princeton University Press.

Sassen, S. (2009). The Specialised Differences of Cities Matter in Today's Global Economy. W: S. Whimster (red.). Reforming the City: Responses to the Global Financial Crisis. London: London Metropolitan University, 209-236.

Soldatos, P. (1987). Le nouvelle generation des villes internationals. Montreal.

Stryjakiewicz, T. (2001). Orientacja teoretyczno-metodologiczna w geografii przemysłu a transformacja gospodarki. Prace Komisji Geografii Przemysłu Polskiego Towarzystwa Geograficznego, 3, 13-25.

Stryjakiewicz, T., Wajda, J. (2003). Organizacja przestrzenna grup kapitałowych jako problem badawczy geografii ekonomicznej. Prace Komisji Geografii Przemysłu Polskiego Towarzystwa Geograficznego, 6, 27-47.

Szymańska, A.I., Płaziak, M. (2014). Enterprise and Classical Factors of its Location on the Market. ProcediaSocial and Behavioral Sciences, 120,13-22.

Śleszyński, P. (2007). Gospodarcze funkcje kontrolne w przestrzeni Polski. Warszawa: Instytut Geografii i Przestrzennego Zagospodarowania Polskiej Akademii Nauk.

Taylor, P.J. (2004). World City Network: A Global Urban Analysis. London: Routledge.

Taylor, P.J., Catalano, G., Walker, D.R.F. (2002). Measurement of the World City Network. Urban Studies, 39(1), 2367-2376.

Taylor, P.J., Csomós, G. (2012). Cities as control and command centres: Analysis and interpretation. Cities, 29(6), 408-411.

Taylor, P.J., Derudder, B., Hoyler, M., Ni, P., Witlox, P. (2014). City-Dyad Analyses of China's Integration into the World City Network. Urban Studies, 51(5), 868-882.

Zioło, Z. (2006). Zróżnicowanie światowej przestrzeni przemysłowej w świetle koncentracji siedzib zarządów wiodących korporacji. Prace Komisji Geografii Przemysłu Polskiego Towarzystwa Geograficznego, $8,9-26$.

Piotr Raźniak, dr, adiunkt, Instytut Geografii, Uniwersytet Pedagogiczny w Krakowie. Do zainteresowań badawczych należą problemy gospodarcze miast, hierarchie miast światowych, problemy funkcjonowania obszarów metropolitalnych, migracje ludności, suburbanizacja. 
Piotr Raźniak, Ph.D. assistant professor at the Institute of Geography of the Pedagogic University, Cracow, Poland. Corporations, hierarchies of world cities, problems of functioning of metropolitan areas, migrations of the population and suburbanization are included in research interests.

Sławomir Dorocki, dr, adiunkt, Zakład Przedsiębiorczości i Gospodarki Przestrzennej, Instytut Geografii, Uniwersytet Pedagogiczny w Krakowie. Absolwent studiów z zakresu geografii społeczno-ekonomicznej Uniwersytetu Pedagogicznego w Krakowie, doktor nauk humanistycznych w dyscyplinie historia (Instytut Europeistyki, Uniwersytet Jagielloński). Adiunkt w Instytucie Geografii Uniwersytetu Pedagogicznego w Krakowie. Zainteresowania badawcze skupiają się wokół problematyki regionów i procesów regionalizacji społeczno-gospodarczej, ze szczególnym uwzględnieniem zróżnicowania przestrzeni europejskiej oraz procesów integracji europejskiej i uwarunkowań historycznych oraz zastosowaniem metod komputerowych i statystycznych w badaniach nad zróżnicowaniem przestrzeni.

Sławomir Dorocki, Ph.D., Department of Entrepreneurship and Spatial Management, Institute of Geography, Pedagogical University of Cracow. Sławomir Dorocki, graduated from Pedagogical University of Cracow, M.Sc. degree in geography, Ph.D. in history (Institute of European Studies of the Jagiellonian University). Associate Professor at the Pedagogical University of Cracow, Institute of Geography. His research interests are tied with regional problems and processes of socio-economic regionalization, with particular emphasis on the diversity of Europe, processes of European integration, historical conditions and application computer and statistical methods in the study of diversity of space.

Anna Winiarczyk-Raźniak, dr, adiunkt, Instytut Geografii, Uniwersytet Pedagogiczny w Krakowie. Do zainteresowań badawczych należą zagadnienia poziomu i jakości życia, rozwój i funkcjonowanie obszarów metropolitalnych, suburbanizacja, geografia społeczna krajów Ameryki Łacińskiej.

Anna Winiarczyk-Raźniak, Ph.D. assistant professor at the Institute of Geography of the Pedagogic University. Research interests include level and quality of life, development and problems of functioning of metropolitan areas, suburbanization and social geography of Latin America.

Monika Płaziak, dr, adiunkt, Zakład Przedsiębiorczości i Gospodarki Przestrzennej, Instytut Geografii, Uniwersytet Pedagogiczny w Krakowie. Zainteresowania badawcze autorki dotyczą zagadnień gospodarki przestrzennej w kontekście czynników lokalizacji przedsiębiorstw, szczególnie czynnika personalnego. Prace badawcze odnoszą się również do zagadnień współpracy jednostek naukowych i badawczo-rozwojowych z sektorem MŚP, zwłaszcza w zakresie wdrażania nowych technologii i materiałów, w tym dotyczących budownictwa energooszczędnego i pasywnego. Ponadto autorka zajmuje się problematyką poziomu i jakości życia ludności, ze szczególnym uwzględnieniem małych i średnich miast Polski oraz miast postsocjalistycznych.

Monika Płaziak, Ph.D., assistant professor in the Department of Entrepreneurship and Spatial Management, Institute of Geography, Pedagogical University of Cracow. Author's research interests concern issues of the spatial development in the context of location factors of enterprises, especially - personal factor. Research works also refer to issues of the cooperation of scientific and research-developmental organizations with the sector of small and medium-sized enterprises, especially in the matter of the implementing new technologies and materials concerning the energy-efficient and passive building. Additionally, the author analyses issues of the level and quality of life, with particular reference to small and medium-sized towns in Poland, and post socialist towns.

Anna Irena Szymańska, dr, adiunkt, Zakład Przedsiębiorczości i Gospodarki Przestrzennej, Instytut Geografii, Uniwersytet Pedagogiczny w Krakowie. Absolwentka studiów z zakresu zarządzania i marketingu Uniwersytetu Ekonomicznego w Krakowie, doktor nauk ekonomicznych w zakresie nauk o zarządzaniu (Katedra Analizy Rynku i Badań Rynkowych - Uniwersytet Ekonomiczny w Krakowie). Adiunkt w Zakładzie Przedsiębiorczości i Gospodarki Przestrzennej Uniwersytetu Pedagogicznego w Krakowie. Zainteresowania badawcze oscylują wokół problematyki potrzeb, preferencji i zachowań rynkowych konsumentów, jak również zagadnień z obszaru przedsiębiorczości i innowacyjności przedsiębiorstw ze szczególnym uwzględnieniem sektora MŚP.

Anna Irena Szymańska, Ph.D., assistant professor in the Department of Entrepreneurship and Spatial Management, Institute of Geography, Pedagogical University of Cracow. Graduated from University of Economics in Krakow, M.Sc. degree in Management and Marketing, Ph.D. degree in economic sciences in the field 
of management sciences (Chair of Market Analysis and Marketing Research - University of Economics in Krakow). Adjunct in the Department of Entrepreneurship and Spatial Management at Pedagogical University of Krakow. Her research interests are related to the issue of consumer needs, preferences and market behaviour as well as issues in the area of entrepreneurship and innovation with particular emphasis on the SME sector.

\title{
Adres/address:
}

\author{
Uniwersytet Pedagogiczny \\ Instytut Geografii \\ Zakład Przedsiębiorczości i Gospodarki Przestrzennej \\ Zakład Geografii Społeczno-Ekonomicznej \\ ul. Podchorążych 2, 30-084 Kraków, Polska \\ e-mail: prazniak@up.krakow.pl (Piotr Raźniak) \\ e:mail: sdorocki@up.krakow.pl (Sławomir Dorocki) \\ e-mail: arazniak@up.krakow.pl (Anna Winiarczyk-Raźniak) \\ e:mail: mplaziak@up.krakow.pl (Monika Płaziak) \\ e:mail: aszym@up.krakow.pl (Anna Irena Szymańska)
}

